\title{
Inhibition of sodium-dependent phosphate transporter NaPi2b function with MX35 antibody
}

\author{
V. S. Gryshkova, V.V. Filonenko, R. G. Kiyamova \\ Institute of Molecular Biology and Genetics NAS of Ukraine \\ 150, Akademika Zabolotnoho St., Kyiv, Ukraine, 03680 \\ filonenko@imbg.org.ua
}

\begin{abstract}
Sodium-dependent phosphate transporter NaPi2b is involved in transport of inorganic phosphate and the maintenance of phosphate homeostasis in human body. NaPi2b was recently identified as a marker of ovarian cancer, termed MX35. Monoclonal antibody (mAb) against transporter NaPi2b, called MX35, demonstrated therapeutic efficacy in radioimmunotherapy of patients with ovarian cancer. Aim. The present experiments explored whether MX35 antibody can affect function of NaPi2b to transport inorganic phosphate ions in cellular models. Methods. HEK293 cells stably expressing wild type NaPi2b and mutant NaPi2b_T330V, which could not be recognized by MX35 antibody, were incubated with MX35 antibody and analyzed by phosphate uptake assay. Results. Cells expressing wild type NaPi2b showed reduced phosphate uptake after incubation with MX35 antibody at concentration $50 \mu \mathrm{g} / \mathrm{ml}$. No significant changes in phosphate transport were detected for cells expressing NaPi2b_T330V at the same experimental conditions. Conclusions. Our results demonstrate 1,8-fold decrease of NaPi2b-mediated phosphate transport in HEK293 cells stably expressing wild type NaPi2b after MX35 antibody application, which can be considered as a specific inhibitor of NaPi2b function.
\end{abstract}

Keywords: NaPi2b, MX35 antibody.

Introduction. Sodium-dependent phosphate transporter NaPi2b (SLC34A2, NaPiIIb, Npt2) is normally expressed in mammalian small intestine at the apical side of enterocyte's brush-border membranes. NaPi2b participates in the transcellular inorganic phosphate $\left(\mathrm{P}_{i}\right)$ absorption, contributing to the maintenance of phosphate homeostasis in the organism [1-3]. The studies on conditional knockout mice demonstrated that $\mathrm{NaPi} 2 \mathrm{~b}$ contributes to $>90 \%$ of total active phosphate absorption [4].

The attempts to generate NaPi2b homozygous deficient mice resulted in death of embryos in uterus soon after implantation, indicating that $\mathrm{NaPi} 2 \mathrm{~b}$ is the major $\mathrm{P}_{i}$ transporter during mouse embryonic development [5].

(c) Institute of Molecular Biology and Genetics, NAS of Ukraine, 2011
The expression of $\mathrm{NaPi} 2 \mathrm{~b}$ mRNA was revealed by Northern blot analysis in many human normal tissues including lung, kidney, liver, prostate, pancreas, testis, ovary, thymus $[1,2]$. The expression of $\mathrm{NaPi} 2 \mathrm{~b}$ on protein level has been detected in normal human salivary glands by Western blotting with polyclonal antibodies against $\mathrm{NaPi} 2 \mathrm{~b}$ [6].

It was reported that alterations in $\mathrm{NaPi} 2 \mathrm{~b}$ expression are linked to several human abnormalities. In lungs, NaPi2b is the only phosphate transporter that is highly expressed, and it is involved in uptake of phosphate for synthesis of surfactant proteins. Deregulation of the NaPi2b transporter function as a result of mutations in SLC34A2 gene may lead to the pulmonary alveolar microlithiasis, autosomal recessively inherited disease, characterized by deposition of calcium-phosphate precipitates in lungs $[7,8]$. 
The increased expression of SLC34A2 gene in cancer was detected in ovarian and papillary thyroid tumors $[9,10]$. Recently, it has been demonstrated that the expression level of SLC34A2 gene is increased in human breast tumors [11]. Low dietary $\mathrm{P}_{i}$ uptake, wellknown regulator of $\mathrm{NaPi} 2 \mathrm{~b}$ expression and function, was shown to cause lung tumorigenesis in K-ras (LA1) model mice on the background of increased $\mathrm{NaPi} 2 \mathrm{~b}$ expression [12].

Previously, we identified $\mathrm{NaPi} 2 \mathrm{~b}$ as an ovarian cancer antigen MX35 by screening cDNA library from OVCAR3 cells with the MX35 antibody [13]. This antibody was generated from mice immunized with a cocktail of human ovarian carcinoma cells and showed reactivity with approximately $90 \%$ samples of human epithelial ovarian cancers [14]. Heterogeneous expression profile of $\mathrm{MX} 35 / \mathrm{NaPi} 2 \mathrm{~b}$ protein was further confirmed for epithelial ovarian tumors of different histomorphological types [15]. The radiolabelled MX35 antibody was used in clinical trials and was shown to possess the therapeutic effect in patients with ovarian cancer $[16,17]$. However, the unlabelled MX35 antibody did not have any therapeutic effect on tumor growth in model mice [18].

Playing an essential role in phosphate homeostasis in a human body $\mathrm{NaPi} 2 \mathrm{~b}$ is considered as a target for inhibition of hyperphosphatemia in patients with chronic renal failure [19]. There are some $\mathrm{P}_{i}$-containing compounds that have been reported as inhibitors of sodiumdependent phosphate transport including phosphonoformic acid, 2V-phosphophloretin, and JTP-59557 [20-22]. But all mentioned inhibitors are not strictly specific for sodium-dependent phosphate transport mediated by NaPi2b.

The identification of MX35 ovarian cancer antigen as sodium-dependent transporter $\mathrm{NaPi} 2 \mathrm{~b}$ gave an opportunity to investigate the impact of specific antibody MX35 on the transport function of NaPi2b. This study aimed to analyze the effect of MX35 antibody on the functioning of sodium-dependent phosphate transporter NaPi2b using cellular models and to determine whether this antibody can function as a specific inhibitor of NaPi2b-mediated phosphate transport.

Materials and methods. Constructs, stable cell line generation. Generation of HEK293 cells stably expressing wild type and mutant forms of $\mathrm{NaPi} 2 \mathrm{~b}$ was previously described [23]. Briefly, human NaPi2b cDNA (NaPi2b_WT) was cloned into $p c D N A 3.1(+)$ («Invitrogen», USA) in the frame with EE-tag. A mutant form of NaPi2b ( $\left.p c D N A 3.1(+) / \mathrm{NaPi} 2 \mathrm{~b} \_\mathrm{T} 330 \mathrm{~V}\right)$ was obtained by site-directed mutagenesis. HEK293 cells were transfected with recombinant plasmids $\left(p c D N A 3.1(+) / \mathrm{NaPi} 2 \mathrm{~b} \_\mathrm{WT}, \quad p c D N A 3.1(+) / \mathrm{NaPi} 2 \mathrm{~b}\right.$ T330V or empty vector) using FuGene («Roshe», Switzerland). Cells were cultured in the presence of G418 antibiotic («Gibco», UK) at the concentration of $1 \mathrm{mg} / \mathrm{ml}$ for 7-10 days to eliminate nontransfected cells before splitting.

Phosphate uptake analysis. HEK293 cells were placed on 96-well plate at $3 \cdot 10^{4}$ cells/well and incubated with the MX35 antibody for different time $(6,12,24$, 48, $96 \mathrm{~h}$ ). The MX35 antibody was kindly provided by Dr. Gerd Ritter (Ludwig Institute for Cancer research, USA). After medium was removed cells were washed 3 times with $200 \mu \mathrm{l}$ of wash solution $(137 \mathrm{mM} \mathrm{NaCl}$, $5.4 \mathrm{mM} \mathrm{KCl}, 2.8 \mathrm{mM} \mathrm{CaCl}_{2}, 1.2 \mathrm{mM} \mathrm{MgSO}_{4}, 14 \mathrm{mM}$ Tris $\mathrm{HCl}(\mathrm{pH} 7.4)) .50 \mu \mathrm{l}$ of assay solution $(0.1 \mathrm{mM}$ $\mathrm{KH}_{2} \mathrm{PO}_{4}, 137 \mathrm{mM} \mathrm{NaCl}, 5.4 \mathrm{mM} \mathrm{KCl}, 2.8 \mathrm{mM} \mathrm{CaCl}_{2}$, $1.2 \mathrm{mM} \mathrm{MgSO}_{4}, 14 \mathrm{mM}$ Tris $\left.\mathrm{HCl}(\mathrm{pH} 7.4)\right)$ with $\left[{ }^{33} \mathrm{P}\right]$ orthophosphate $(1 \mu \mathrm{Ci} / \mathrm{ml})$ was added to each well and incubated at room temperature. Then, assay solution was removed and cells were rinsed 3 times with $150 \mu \mathrm{l}$ of ice-cold stop solution (137 mM NaCl, $14 \mathrm{mM}$ Tris $\mathrm{HCl}(\mathrm{pH}$ 7.4)). Cells were lysed in $50 \mu \mathrm{l}$ of lysis buffer (0.01 M Tris HCl, pH 7.5, 0.15 M NaCl, 0.01 $\mathrm{M} \mathrm{MgCl}_{2}$, $0.5 \% \mathrm{NP}-40)$ and $25 \mu \mathrm{l}$ of cell lysate was used to determine radioactivity in a liquid scintillation counter («Perkin Elmer», USA). The rest of cell lysate was used to determine protein concentration using BCA protein assay kit («Pierce Biotechnology», USA). To inhibit sodium-dependent phosphate transport phosphonoformic acid («Sigma», USA) was added to the assay solution at $5 \mathrm{mM}$ concentration.

Western blot analysis. HEK293 cells were lysed in buffer containing $10 \mathrm{mM}$ Tris-HCI, pH 7.5, $150 \mathrm{mM}$ $\mathrm{NaCl}, 10 \mathrm{mM} \mathrm{MgCl}{ }_{2}, 0.5 \% \mathrm{NP}-40$ and a mixture of Halt Protease Inhibitor Cocktail («Pierce», USA). Protein concentration was estimated by Comassie Assay («Pierce»). Protein samples were separated by $10 \%$ SDS/PAGE and electrotransferred on polyvinylidene difluoride (PVDF) membrane («Millipore», USA). The membranes were blocked with $3 \%$ BSA in $1 \times$ 


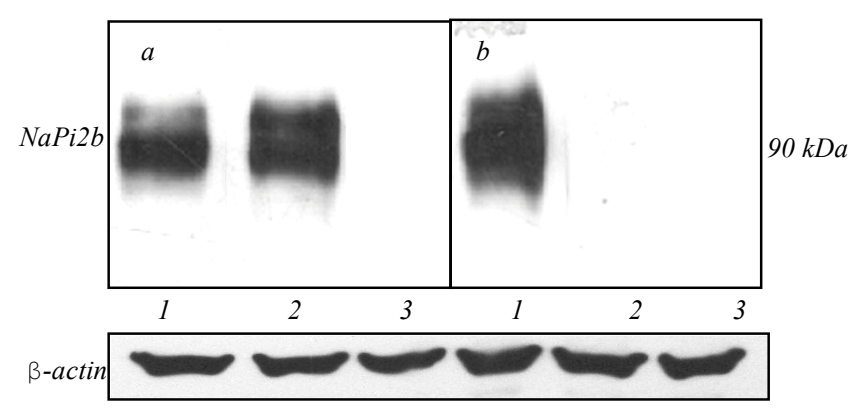

Fig. 1. Western blot analysis of HEK293 cells expressing wild type NaPi2b (1), mutant form NaPi2b_T330V (2) and cells transfected with empty $p c D N A 3.1(+)$ vector (3) by anti-EE-tag $(a)$ and MX35 (b) antibodies; $\beta$-actin was used as a loading control

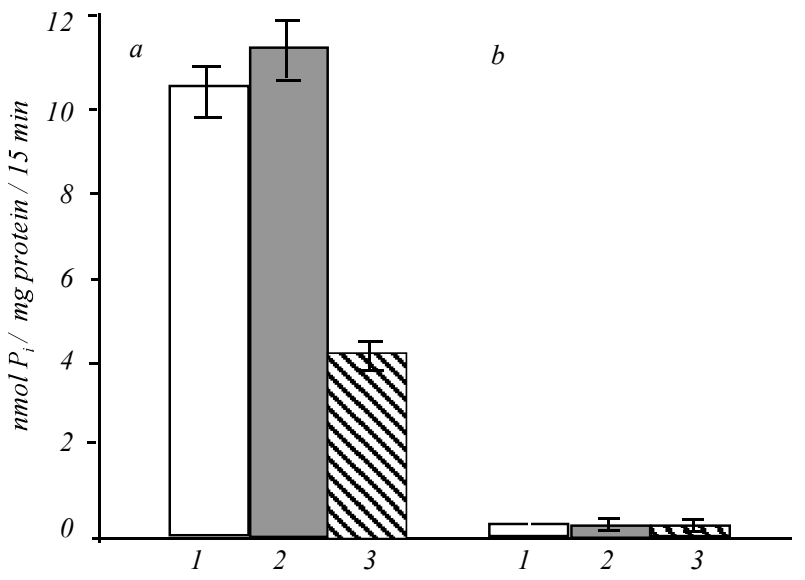

Fig. 2. The results of phosphate uptake assay on HEK293 stable cell lines expressing wild type $\mathrm{NaPi} 2 \mathrm{~b}(1)$, mutant form NaPi2b_T330V (2) and cells transfected with empty $p c D N A 3.1 .(+)$ vector $(3)(a)$; phosphate uptake assay of the same cell lines after treatment with phosphonoformic acid at $5 \mathrm{mM}$ concentration $(b)$. Cells were incubated in assay solution for $15 \mathrm{~min}$ at RT

$\times$ PBST for $1 \mathrm{~h}$ at RT and incubated with the MX35 antibody at $4{ }^{\circ} \mathrm{C}$ overnight. After incubation with HRP-conjugated goat anti-mouse IgG («Promega», USA) the membranes were developed using the ECL system («Amersham», Sweden) and then exposed to Agfa X-ray film.

Statistical analysis. Data are provided as means \pm \pm SEM. All experiments were repeated 3 times; in all repetitions qualitatively similar data were obtained.

Results and discussion. Sodium-dependent phosphate transporter $\mathrm{NaPi} 2 \mathrm{~b}$, which plays an essential role in the maintenance of phosphate homeostasis in the human body, was revealed as ovarian cancer marker MX35 [13]. It has been shown that the radiolabelled MX35 antibody recognizing NaPi2b has therapeutic effect in patients with ovarian cancer and $\mathrm{F}(\mathrm{ab})_{2}$ fragments of the MX35 antibody specifically localize in micrometastatic loci within peritoneal cavity $[16,17]$. Knowledge about the function of MX35 antigen provided the basis for the investigation of the MX35 antibody impact on the phosphate transport function of MX35/NaPi2b protein.

To investigate the function of $\mathrm{NaPi} 2 \mathrm{~b}$ as a transporter of inorganic phosphate we applied a phosphate uptake assay using HEK293 cells expressing the wild type and mutant form of NaPi2b as well as HEK293 cells transfected with empty $p c D N A 3.1(+)$ plasmid as a control. In the predicted topology of NaPi2b, both $\mathrm{N}$ and C-terminal tails face cytoplasm, exposing loops of various length to the extracellular and intracellular compartments including a large extracellular loop (188-361 aa). Previously, we have shown that the epitope recognized by MX35 antibody is located within the predicted extracellular domain (311-340 aa) [13, 24]. Further studies have shown that the mutation $\mathrm{T} 330 \mathrm{~V}$ in the large extracellular loop of NaPi2b transporter is crucial for the recognition of $\mathrm{NaPi} 2 b$ by the MX35 antibody [23]. Western blot analysis of lysates of cell lines stably expressing the wild type and mutant form (NaPi2b_T330V) of transporter clearly indicated that mutant NaPi2b_T330V was not recognized by the MX35 antibody whereas both wild type and mutant form were recognized well by the EE-tag specific antibody (Fig. 1).

We applied a phosphate uptake assay to investigate the $\mathrm{NaPi} 2 \mathrm{~b}$ transport function in the cells expressing wild type $\mathrm{NaPi} 2 \mathrm{~b}$ and in the control cell line. In timecourse study, the human NaPi2b-mediated $\mathrm{P}_{i}$ uptake increased linearly up to $30 \mathrm{~min}$, thus 15 min uptake time was used to evaluate phosphate uptake in further experiments (data not shown).

At this uptake time we observed 2.5-fold increase in $\mathrm{P}_{i}$ uptake in the cells expressing wild type $\mathrm{NaPi} 2 \mathrm{~b}$ $(10.6 \pm 0.6 \mathrm{nmol} / \mathrm{mg}$ protein) in contrast to the cells transfected with empty $p c D N A 3.1(+)$ plasmid $(4.2 \pm$ $\pm 0.4 \mathrm{nmol} / \mathrm{mg}$ protein) (Fig. 2). The cells expressing the mutant form NaPi2b_T330V transported inorganic phosphate with the same efficiency as the cells expressing the wild type of NaPi2b $(11.5 \pm 0.7 \mathrm{nmol} / \mathrm{mg}$ protein) (Fig. 2). The use of well-known inhibitor of sodium-dependent phosphate transport phosphonofor- 


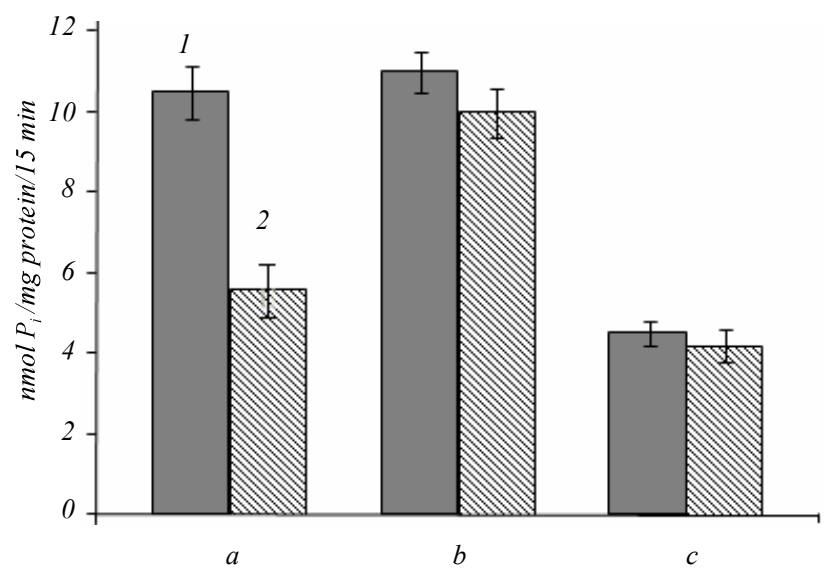

Fig. 3. The results of phosphate uptake assay on stable cell lines expressing wild type NaPi2b $(a)$, mutant form NaPi2b_T330V $(b)$ and control cell line (c) without (1) and with (2) MX35 antibody at concentration $50 \mu \mathrm{g} / \mathrm{ml}$ during $24 \mathrm{~h}$

mic acid at $5 \mathrm{mM}$ concentration in assay solution led to the total abolishment of $\mathrm{P}_{i}$ uptake in all the investigated cell lines (Fig. 2).

To determine the effect of MX35 antibody on $\mathrm{NaPi} 2 \mathrm{~b}$-mediated transport we performed the phosphate uptake experiments for all mentioned cell lines after incubation with the MX35 antibody at different concentrations $(5,10,20$, and $50 \mu \mathrm{g} / \mathrm{ml})$ and different time $(6,12,24,48,96 \mathrm{~h})$ (data not shown). We detected a considerable inhibition of phosphate uptake in the cells expressing wild type of $\mathrm{NaPi} 2 \mathrm{~b}$ incubated for $24 \mathrm{~h}$ with the MX35 antibody at concentration of $50 \mu \mathrm{g} / \mathrm{ml}$. In this case 1,8-fold decrease in sodium-dependent phosphate uptake was observed for the wild type $\mathrm{NaPi} 2 \mathrm{~b}$ (incubation with antibody $-10.52 \pm 0.65 \mathrm{nmol} / \mathrm{mg}$; incubation without antibody $-5.6 \pm 0.45 \mathrm{nmol} / \mathrm{mg}$ ). At the same time phosphate transport in the cell line transfected with empty $p c D N A 3.1(+)$ plasmid remained unchanged (incubation with antibody $-4.5 \pm 0.3 \mathrm{nmol} /$ $\mathrm{mg}$ protein; incubation without antibody $-4.2 \pm$ $\pm 0.4 \mathrm{nmol} / \mathrm{mg}$ ) (Fig. 3).

To confirm the specificity of this inhibition we evaluated the effect of MX35 antibody on the cells expressing the mutant form NaPi2b_T330V, which is not recognized by the MX35 antibody. No significant changes were detected in the phosphate uptake measurements in the cells expressing NaPi2b_T330V after incubation with the MX35 antibody $(11.5 \pm 0.7 \mathrm{nmol} /$ mg protein; $10 \pm 0.5 \mathrm{nmol} / \mathrm{mg}$ protein) (Fig. 3). Our data clearly demonstrate that the MX35 antibody specific to NaPi2b transporter significantly decreased sodium-dependent phosphate uptake in the cellular models used in this study.

The mechanism of remarkable inhibition of sodium-dependent phosphate transport by the antibody specific to extracellular domain of $\mathrm{NaPi} 2 \mathrm{~b}$ still remains unknown. It should be further investigated whether the incubation of the cells expressing $\mathrm{NaPi} 2 \mathrm{~b}$ with the MX35 antibody may lead to down regulation of $\mathrm{NaPi} 2 \mathrm{~b}$ protein decreasing the number of transporter units on cell surface or the binding of MX35 antibody can cause conformational changes in transporter structure affecting its function and vice versa it can prevent conformational changes necessary for transporter functioning.

Conclusions. Using cellular models expressing the wild type and mutant NaPi2b_T330V transporter we showed that the MX35 antibody directed against $\mathrm{NaPi} 2 \mathrm{~b}$ significantly decreased phosphate uptake mediated by NaPi2b and, thus, can be considered as a specific inhibitor of $\mathrm{NaPi} 2 \mathrm{~b}$ transport function.

Acknowledgments. V. Gryshkova was supported by Boehringer Inhelheim Fonds (BIF) travel grant to perform the part of this work at the University College London under I. Gout supervision.

\section{В. С. Гричкова, В. В. Філоненко, Р. Г. Кіямова}

Інгібування функції натрій-залежного транспортера фосфатів $\mathrm{NaPi2b} \mathrm{специфічними} \mathrm{антитілами} \mathrm{МХ35}$

\section{Резюме}

Натрій-залежний транспортер фосфату NaPi2b бере участь y перенесенні неорганічного фосфату та підтриманні фосфатного гомеостазу в організмі людини. Нещодавно NaPi2b описано як маркер раку яєчника МХ35. Моноклональні антитіла (МКАТ) проти транспортера NaPi2b, які отримали назву МХ35, виявляють терапевтичну ефективність при лікуванні хворих на рак яєчника. Мета даної роботи полягала в тому, щуоб з 'ясувати, чи впливає зв 'язування MКАT MX35 з NaPi2b на його функиію транспортувати іони неорганічного фосфату в клітинних моделях. Методи. Клітини лінї НЕК293, щзо стабільно експресують дикий mип NaPi2b та мутантну форму NaPi2b_T330V, яка не розпізнається антитілами $М X 35$, інкубували з антитілами $М X 35$, після чого аналізували поглинання клітинами радіоактивно міченого фосфату. Результати. Після інкубації з антитілами МХЗ5 у концентрації 50 мкг/мл відмічено значне зменшення поглинання фосфату клітинами, які експресують дикий тип NaPi2b. Для клітин, щуо експресують мутантну форму NaPi2b_T330V, за аналогічних експериментальних умов значних змін у поглинанні фосфату не виявлено. Висновки. Наші дані свідчать про 1,8-разове 
зниження $\mathrm{NaPi} 2 \mathrm{~b}$-залежного транспорту фосфату в результаті інкубації з МКАТ МХ35, які можуть слугувати специфічним інгібітором функиї NaPi2b.

Ключові слова: NaPi2b, моноклональні антитіла МX35.

\section{В. С. Гриикова, В. В. Филоненко, Р. Г. Киямова}

Ингибирование функции натрий-зависимого транспортера фосфатов NaPi2b специфическими антителами MX35

\section{Резюме}

Натрий-зависимыц̆ транспортер фосфата NaPi2b участвует в переносе неорганического фосфата и поддержании фосфатного гомеостаза в организме человека. Недавно NaPi2b описан как маркер рака яичника МХ35. Моноклональные антитела (МКАТ) против транспортера NaPi2b, названные MX35, проявляют терапевтическую эффективность при лечении больных раком яичника. Цель данной работы состояла в выяснении того, влияет ли связывание МКАТ MX35 с NaPi2b на его функцию транспортировать ионы неорганического фосфата в клеточных моделях. Методы. Клетки линии НЕК293, стабильно экспрессирующие дикий тип NaPi2b и мутантную форму NaPi2b_T330V, не распознаваемую антителами $M X 35$, инкубировали с антителами $M X 35$, после чего анализировали поглощение клетками радиоактивно меченного фосфата. Результатьы. После инкубации с антителами МХ35 в кониентрации 50 мкг/мл отмечено значительное уменьшение поглощения фосфата клетками, экспрессирующими дикий тип NaPi2b. Для клеток, экспрессирующих мутантную форму транспортера NaPi2b_T330V, не выявлено существенных изменений в поглощении фосфата при аналогичных экспериментальных условиях. Выводы. Наши результаты свидетельствуют о 1,8-кратном снижении NaPi2b-зависимого транспорта фосфата в результате инкубации с МКАТ МХ35, которые можно рассматривать как специфический ингибитор функции NaPi2b.

Ключевые слова: NaPi2b, моноклональные антитела МХ35.

\section{REFERENCES}

1. Xu H., Bai L., Collins J. F., Ghishan F. K. Molecular cloning, functional characterization, tissue distribution, and chromosomal localization of a human, small intestinal sodium-phosphate $\left(\mathrm{Na}^{+}-\mathrm{P}_{i}\right)$ transporter (SLC34A2) // Genomics.-1999.-62, N 2.P. 281-284.

2. Hilfiker H., Hattenhauer O., Traebert M., Forster I., Murer H., Biber J. Characterization of a murine type II sodium-phosphate cotransporter expressed in mammalian small intestine // Proc. Natl Acad. Sci. USA.-1998.-95, N 24.-P. 14564-14569.

3. Virkki L. V., Biber J., Murer H., Forster I. C. Phosphate transporters: a tale of two solute carrier families // Am. J. Physiol. Renal. Physiol.-2007.-293, N 3.-P. F643-F654.

4. Sabbagh Y., O'Brien S. P., Song W., Boulanger J. H., Stockmann A., Arbeeny $C$., Schiavi $S$. C. Intestinal Npt2b plays a major role in phosphate absorption and homeostasis // J. Am. Soc. Nephrol.-2009.-20, N 11.-P. 2348-2358.

5. Shibasaki Y., Etoh N., Hayasaka M., Takahashi M. O., Kakitani M., Yamashita T., Tomizuka K., Hanaoka K. Targeted deletion of the type IIb $\mathrm{Na}(+)$-dependent $\mathrm{P}_{i}$-co-transporter, $\mathrm{NaPi}$-IIb, results in early embryonic lethality // Biochem. Biophys. Res. Commun.-2009.-381, N 4.-P. 482-486.

6. Homann V., Rosin-Steiner S., Stratmann T., Arnold W. H., Gaengler P., Kinne R. K. Sodium-phosphate cotransporter in hu- man salivary glands: molecular evidence for the involvement of $\mathrm{NPT} 2 \mathrm{~b}$ in acinar phosphate secretion and ductal phosphate reabsorption // Arch. Oral. Biol.-2005.-50, N 9.-P. 759-768.

7. Corut A., Senyigit A., Ugur S. A., Altin S., OzcelikU., Calisir H., Yildirim Z., Gocmen A., Tolun A. Mutations in SLC34A2 cause pulmonary alveolar microlithiasis and are possibly associated with testicular microlithiasis // Am. J. Hum. Genet.-2006.-79, N 4.-P. 650-656.

8. Huqun, Izumi S., Miyazawa H., Ishii K., Uchiyama B., Ishida T., Tanaka S., Tazawa R., Fukuyama S., Tanaka T., Nagai Y., Yokote A., Takahashi H., Fukushima T., Kobayashi K., Chiba H., Nagata M., Sakamoto S., Nakata K., Takebayashi Y., Shimizu Y., Kaneko K., Shimizu M., Kanazawa M., Abe S., Inoue Y., Takenoshita S., Yoshimura K., Kudo K., Tachibana T., Nukiwa T., Hagiwara $K$. Mutations in the $S L C 34 A 2$ gene are associated with pulmonary alveolar microlithiasis // Am. J. Respir. Crit. Care Med.-2007.-175, N 3.-P. 263-268.

9. Rangel L. B., Sherman-Baust C. A., Wernyj R. P., Schwartz D. R., Cho K. R., Morin P. J. Characterization of novel human ovarian cancer-specific transcripts (HOSTs) identified by serial analysis of gene expression // Oncogene.-2003.-22, N 46.P. 7225-7232.

10. Jarzab B., Wiench M., Fujarewicz K., Simek K., Jarzab M., Oczko-Wojciechowska M., Wloch J., Czarniecka A., Chmielik E., Lange D., Pawlaczek A., Szpak S., Gubala E., Swierniak A. Gene expression profile of papillary thyroid cancer: sources of variability and diagnostic implications // Cancer Res.-2005.-65, N 4.-P. 1587-1597.

11. Chen D. R., Chien S. Y., Kuo S. J., Teng Y. H., Tsai H. T., Kuo J. $H$., Chung J. G. SLC34A2 as a novel marker for diagnosis and targeted therapy of breast cancer // Anticancer Res.-2010.-30, N 10.-P. 4135-4140.

12. Xи C. X., Jin H., Lim H. T., Ha Y. C., Chae C. H., An G. H., Lee $K$. H., Cho M. H. Low dietary inorganic phosphate stimulates lung tumorigenesis through altering protein translation and cell cycle in K-ras (LA1) mice // Nutr. Cancer.-2010.-62, N 4.P. 525-532.

13. Yin B. W., Kiyamova R., Chua R., Caballero O. L., Gout I., Gryshkova V., Bhaskaran N., Souchelnytskyi S., Hellman U., Filonenko V., Jungbluth A. A., Odunsi K., Lloyd K. O., Old L. J., Ritter $G$. Monoclonal antibody MX35 detects the membrane transporter NaPi2b (SLC34A2) in human carcinomas // Cancer Immun.-2008.-8.-P. 3.

14. Mattes M. J., Look K., Furukawa K., Pierce V. K., Old L. J., Lewis J. L. Jr., Lloyd K. O. Mouse monoclonal antibodies to human epithelial differentiation antigens expressed on the surface of ovarian carcinoma ascites cells // Cancer Res.-1987.-47, N 24 (Pt 1).-P. 6741-6750.

15. Gryshkova V., Goncharuk I., Gurtovyy V., Khozhayenko Y., Nespryadko S., Vorobjova L., Usenko V., Gout I., Filonenko V., Kiyamova $R$. The study of phosphate transporter NAPI2B expression in different histological types of epithelial ovarian cancer // Exp. Oncol.-2009.-31, N 1.-P. 37-42.

16. Rubin S. C., Kostakoglu L., Divgi C., Federici M. G., Finstad C. L., Lloyd K. O., Larson S. M., Hoskins W. J. Biodistribution and intraoperative evaluation of radiolabeled monoclonal antibody MX35 in patients with epithelial ovarian cancer // Gynecol. Oncol.-1993.-51, N 1.-P. 61-66.

17. Andersson H., Cederkrantz E., Back T., Divgi C., Elgqvist J., Himmelman J., Horvath G., Jacobsson L., Jensen H., Lindegren S., Palm S., Hultborn R. Intraperitoneal alpha-particle radioimmunotherapy of ovarian cancer patients: pharmacokinetics and 
dosimetry of (211)At-MX35 F(ab')2 - a phase I study // J. Nucl. Med.-2009.-50, N 7.-P. 1153-1160.

18. Elgqvist J., Andersson H., Back T., Hultborn R., Jensen H., Karlsson B., Lindegren S., Palm S., Warnhammar E., Jacobsson $L$. Therapeutic efficacy and tumor dose estimations in radioimmunotherapy of intraperitoneally growing OVCAR-3 cells in nude mice with (211)At-labeled monoclonal antibody MX35 // J. Nucl. Med.-2005.-46, N 11.-P. 1907-1915.

19. Malluche H. H., Monier-Fangere M. C. Hyperphosphatemia: pharmacologic intervention yesterday, today and tomorrow // Clin. Nephrol.-2000.-54, N 4.-P. 309-317.

20. Loghman-Adham M., Levi M., Scherer S. A., Motock G. T., Totzke M. T. Phosphonoformic acid blunts adaptive response of renal and intestinal $P_{i}$ transport // Am. J. Physiol.-1993.-265, N 6 (Pt 2).-P. F756-763.

21. Peerce B. E., Clarke R. A phosphorylated phloretin derivative. Synthesis and effect on intestinal $\mathrm{Na}(+)$-dependent phosphate absorption // Am. J. Physiol. Gastrointest. Liver Physiol.2002.-283, N 4.-P. G848-855.
22. Matsuo A., Negoro T., Seo T., Kitao Y., Shindo M., Segawa H., Miyamoto K. Inhibitory effect of JTP-59557, a new triazole derivative, on intestinal phosphate transport in vitro and in vivo // Eur. J. Pharmacol.-2005.-517, N 1-2.-P. 111-119.

23. Gryshkova V. S., Lituyev D. S., Filonenko V. V., Kiyamova R. G. Creation of cellular models for the analysis of sodium-dependent phosphate transporter $\mathrm{NaPi} 2 \mathrm{~b}$, a potential marker for ovarian cancer // Biopolym. Cell.-2009.-25, N 2.-P. 95-100.

24. Kiyamova R., Gryshkova V., Ovcharenko G., Lituyev D., Malyuchik S., Usenko V., Khozhayenko Y., Gurtovyy V., Yin B., Ritter G., Old L., Filonenko V., Gout I. Development of monoclonal antibodies specific for the human sodium-dependent phosphate co-transporter NaPi2b // Hybridoma.-2008.-27, N 4.-P. 277284.

UDC 577.2, 577.27

Received 25.12.10 